\title{
MASSIVE PERICARDIAL EFFUSION WITH CHOLESTEROL CRYSTALS TREATED BY PERICARDECTOMY
}

\author{
BY \\ S. G. GRIFFIN AND W. G. A. SWAN \\ From Seaham Hall Hospital and Newcastle General Hospital
}

Pericardial effusion containing a large amount of cholesterol is a rare condition. The first description is British (Alexander, 1919). Alexander's patient evidently had myxœdema but the pericardial effusion failed to absorb with thyroid treatment and incision of the pericardium was performed. Alexander was the first to use the expression "gold paint" to describe the peculiar glistening and scintillating appearance of the pericardial fluid. Unfortunately the subsequent fate of this patient was not described.

Large pericardial effusions containing cholesterol in patients with myxœdema were described by Harrell and Johnston (1943) and Bullrich, Repetto, and Ferrari (1944), but these cleared up with replacement therapy. A fatal case in myxœdema was that of Howard (1946) in which the pericardium and epicardium were thickened and covered with yellow deposits of cholesterol.

Other cases resembling Alexander's are described by Merrill (1938), in which thyroid treatment did not cause absorption and aspiration resulted in improvement, and by Duclos et al. (1962) who resorted to successful pericardectomy under similar circumstances. In this case histological examination of the pericardium showed subendothelial granulation tissue with macrophages, giant cells, and cholesterol clefts.

Eleven other patients, excluding the present one, are described, in whom myxœdema was not present and no obvious ætiology could be found (Table). Two were brothers (Genecin, 1959), two were elderly subjects with hypertension (Claisse et al., 1961), and three had suffered from polyarthritis (Arnold and Maurice, 1961). Age and sex do not appear to be significant factors. The effusion seems to have been the direct cause of death in only one case (Moe and Campos, 1957) in which the thickened pericardium showed yellow patches, cholesterol clefts, and histiocytes with foamy cytoplasm.

Aspiration alone has brought about improvement (Ada, Jones, and Sheeran, 1950) or apparent cure (Claisse et al., 1961). Aspiration with intrapericardial injection of heparin was used by Arnold and Maurice (1961) with apparent success in one case, but in another pericardectomy had to be done and was successful. Aspiration was followed by adhesion of the pericardium in the case of Creech et al. (1955) and a successful pericardectomy was performed. A cure lasting eight years after pericardectomy is reported by Haining and Haining (1961).

Histological examination of the pericardium removed at operation reveals the same general picture. Fibrous thickening with non-specific inflammatory reaction, macrophages, giant cells, and cholesterol clefts are uniform findings. Tuberculosis has not been found in any case.

The striking appearance of the pericardial fluid is always apparent from these reports. "Scintillating", "fluorescent", "satiny", and "gold paint" are epithets used. The colour described varies from yellow to dark green. Large numbers of cholesterol crystals are a constant finding and cells are scanty. No micro-organisms of any kind are recorded. The cholesterol content of the pericardial fluid, where it is given, ranges from 95 to $263 \mathrm{mg} . / 100 \mathrm{ml}$. In non-myxœdematous patients it may exceed the level of the serum cholesterol (Creech et al., 1955). 
TABLE

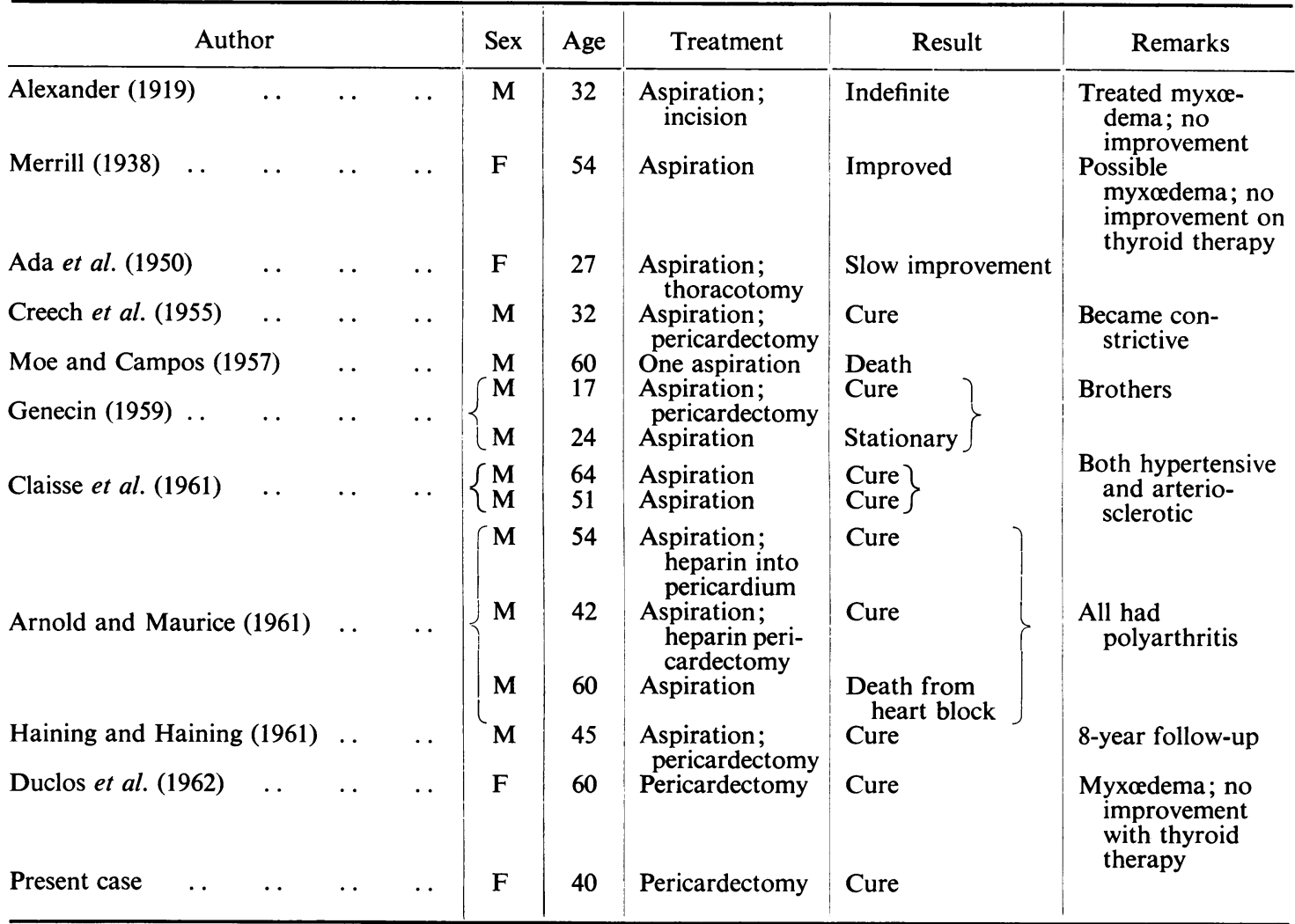

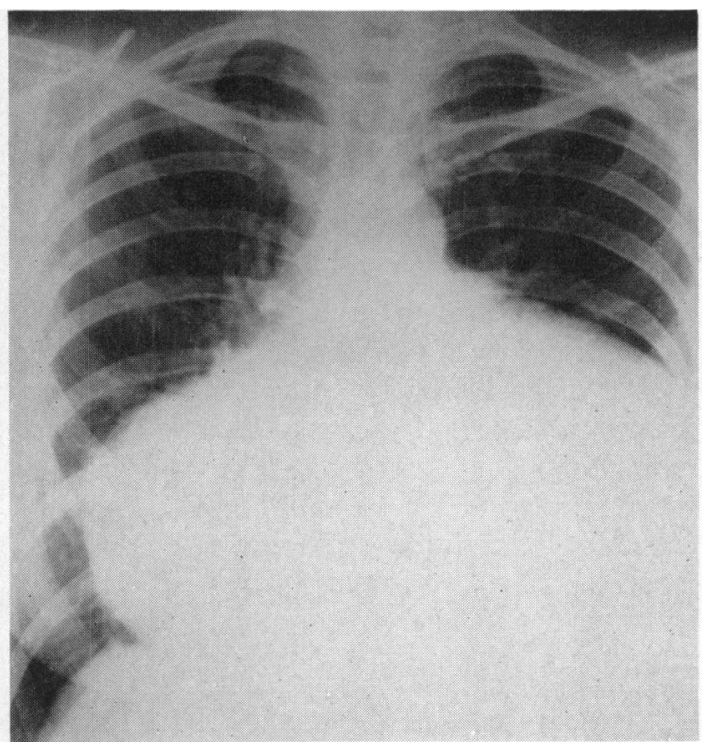

FIG. 1.-Radiograph of chest on September 18, 1961 showing typical pre-operative appearance of a large pericardial effusion.

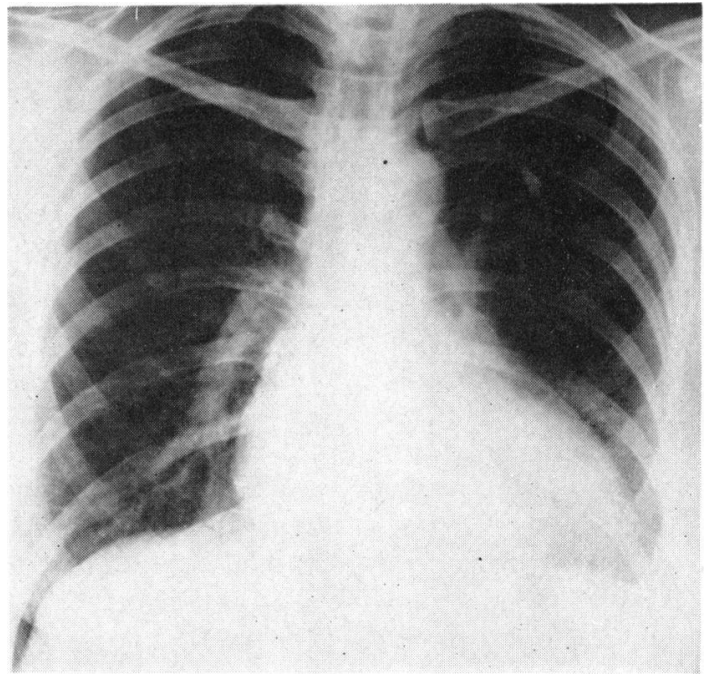

FIG. 2.-Radiograph of chest on September 26, 1962 , after recovery, showing very slight cardiac enlargement. 
In no patient is there any evidence of previous pericardial disease, with the possible exception of Arnold and Maurice's (1961) three patients who had suffered from attacks of polyarthritis.

\section{Case Report}

A European housewife, aged 40, was admitted on October 10,1960, complaining of breathlessness on exertion of three months' duration. Before this she had been perfectly well. In 1957 her chest had been $x$-rayed and no comment was made. Her own doctor had found much increase in cardiac dullness and sent her for a chest film which showed gross enlargement of the heart shadow.

On admission she was in no distress and was afebrile. Her nutrition was average and her appearance was normal. There was no clinical evidence of myxœdema. The pulse was 78 a minute and regular. The blood pressure was $130 / 90 \mathrm{~mm}$. Hg. The jugular veins were distended up to $3 \mathrm{in}$. $(7 \cdot 6 \mathrm{~cm}$.) above the clavicle, but they did not pulsate. There was a little odema of the ankles. The liver's edge could be felt one finger's breadth below the costal margin. There was gross increase in the area of cardiac dullness which extended upwards to the second left rib and laterally to the anterior axillary line and also to the right of the sternum. The heart sounds were faint. A third sound was present. There was no pericardial friction at any time. There was diminished air entry at the left lung base with bronchial breath sounds and crepitations.

A chest film showed gross enlargement of the heart shadow (Fig. 1). The lung fields were normal. Screening showed much diminution of cardiac pulsation. The electrocardiogram showed normal rhythm and low voltage of the QRST complex in all leads.

Paracentesis of the pericardium yielded a yellow turbid fluid which glistened exactly like gold paint when agitated: $40 \mathrm{ml}$. were withdrawn and air was injected. A further chest film showed a small amount of air in the pericardial cavity and very little thickening of the parietal pericardium. Further aspirations of 500 and $1800 \mathrm{ml}$. of fluid were made during the next week. This resulted in a slight reduction of the heart shadow and in the disappearance of jugular venous distension, œdema, and hepatic enlargement. The electrocardiogram became normal. She was discharged after three weeks.

She was readmitted in January 1961 for further pericardial aspiration and $1500 \mathrm{ml}$. of the same turbid glistening fluid were removed. After this there was moderate reduction in the size of the heart shadow.

For a year she remained well and able to do her housework and shopping. The heart shadow, however, began to increase in size and in March 1962 she again complained of dyspnœa. The jugular veins were once more distended and there was a little œdema of the ankles, but no hepatic enlargement and no ascites. She was readmitted in March 1962 and it was decided to perform a pericardectomy.

Laboratory Data. Hæmoglobin 14.0 g./100 ml.; packed cell volume, 49 per cent, leucocytes $5500 /$ c.mm.; blood Wassermann reaction negative; serum cholesterol $203 \mathrm{mg} . / 100 \mathrm{ml}$.; basal metabolic rate +3 per cent. Pericardial fluid: protein $6.0 \mathrm{~g}$. $/ 100 \mathrm{ml}$.; cholesterol $190 \mathrm{mg} . / 100 \mathrm{ml}$; crystals of cholesterol present; no cells seen; no acid-fast bacilli; $M$. tuberculosis not found on culture.

Operation. April 26, 1962. A partial parietal pericardectomy was carried out through the left fifth intercostal space: $10 \mathrm{oz}$. (283 g.) of opalescent yellow fluid was aspirated from the pleura; a firm yellow nodule $0.5 \mathrm{~cm}$. in diameter in the fifth interspace anteriorly was resected.

From a number of soft yellow masses scattered in the pleura one was resected from the fourth space anteriorly. Some tissue that looked like pericardial fat was also removed. The lungs felt normal. The flabby distended pericardium was opened and approximately one pint of similar yellow turbid fluid was evacuated. After freeing the phrenic nerve bundle the parietal pericardium over the anterior and left lateral aspects of the heart was excised. The edges of the pericardium were sutured for hæmostasis. The pericardium looked smooth and only slightly thickened. A few firm plaques were felt on the intrapericardial aorta. The chest wound was closed in the usual way with eighth intercostal space drainage posterolaterally; and the intercostal tube was removed on the third day. The post-operative course was uninterrupted and she returned home after a month.

Post-operative Progress. The patient has remained well. She is active and not short of breath. When last seen, in November 1962, her general condition was excellent and she made no complaint. Physical examination of the heart and lungs showed no abnormalities. A chest film (Fig. 2) showed only slight cardiac enlargement, the cardiothoracic ratio being 59 per cent. The lung fields were normal. The electrocardiogram since operation has been abnormal showing low $\mathrm{T}$ waves with shallow inversion in leads II, III, AVF, and V4-7, but these changes, which are probably due to epicardial disturbance, are becoming less apparent.

Pathological Findings. The pericardium was thickened to an average of $2 \mathrm{~mm}$. The internal surface 
was smooth with a dull greyish-white appearance; the external surface showed areas of irregular thickening and small discrete bright yellow deposits lying superficially. The cut surface had a laminated appearance suggesting areas of fibrosis of different ages and in the deeper parts small yellow deposits could be seen. Histological examination showed a grossly thickened pericardium, the greatest thickness being contributed by acellular fibrous tissue. Within this there were numerous foci of inflammatory cells, mostly lymphocytes but some plasma cells and occasionally eosinophils around blood vessels and in some of these foci there were small groups of macrophages containing doubly refractile material. Larger foci of macrophages also filled with doubly refractile material were also present, these constituting the yellow patches seen by the naked eye. In these areas there were a fair number of multinucleated giant cells but very little other inflammatory cell collection.

In the specimen thought to be epicardial fat there was much proliferation of mesothelial cells, much of it in the form of papillary processes, and between the foci were large numbers of lipid-laden phagocytes. In addition peculiar rounded lesions were seen with a fibrous capsule containing lipid material and cells in various stages of degeneration. One of these lesions was partly calcified. The pleural lesion showed proliferation of pleural mesothelial cells some of which contained lipid material. Foci of phagocytes and large giant cells containing lipid were also present. There was a mild infiltration of plasma cells and eosinophils.

\section{Summary}

It is established that massive pericardial effusion with a high cholesterol content can occur in patients with myxœdema and that the effusion may not absorb when the patient receives thyroid treatment. A similar effusion may occur rarely in euthyroid patients without any obvious explanation. Aspiration may lead to apparent cure or to pericardial adhesion but pericardectomy seems to be the treatment of choice.

A case is described in which a massive pericardial effusion with cholesterol crystals was found in an otherwise normal woman of 40 years of age. The effusion re-formed in spite of aspiration. Pericardectomy was performed and the patient was completely relieved.

We would like to thank Dr. B. E. Tomlinson and Dr. D. A. Leslie for their reports on the material removed at operation.

\section{References}

Ada, A. E. W., Jones, O. R., and Sheeran, A. D. (1950). Cholesterol pericarditis. J. thorac. Surg., $20,28$.

Alexander, J. S. (1919). A pericardial effusion of "gold paint" appearance due to the presence of cholesterin. Brit. med. J., 2, 463.

Arnold, E. F., and Maurice, P. (1961). Trois observations de péricardite chronique à cristaux de cholestérol. Cardiologia (Basel), 38, 85 .

Bullrich, R. A., Repetto, R., and Ferrari, J. A. (1944). Derrame pericárdico mixedematoso. Tamponamiento cardíaco crónico. Pren. méd. argent., 31, 2423.

Claisse, R., Di Matteo, J., Danel, J., Suquet, Y., Segresta, J. M., and Jean-Casal, C. (1961). Epanchements péricardiques chroniques d'origine indeterminée. Bull. Soc. méd. Hôp. Paris, 4th series, 77, 935.

Creech, O., Hicks, W. M., Snyder, H. B., and Erickson, E. E. (1955). Cholesterol pericarditis; successful treatment by pericardiectomy. Circulation, 12, 193.

Duclos, F., Zambrano, A., Bohorquez, A., Mora, I., and Bermudo, J. (1962). Péricardite à cholestérol. Traitement chirurgicale. Arch. Mal. Cour, 55, 675.

Genecin, A. (1959). Chronic pericardial effusion in brothers, with a note on "cholesterol pericarditis". Amer. J. Med., 26, 496.

Haining, R. B., and Haining, R. G. (1961). Cholesterol pericarditis. Ann. intern. Med., 54, 300.

Harrell, G. T., and Johnston, C. (1943). Pericardial effusion in myxedema. Amer. Heart J., $25,505$.

Howard, J. W. (1946). Myxedema with cholesterosis and massive pericardial effusion. Delaware St. med. J., 18, 150.

Merrill, A. J. (1938). Cholesterol pericarditis: report of a case. Amer. Heart J., 16, 505.

Moe, A. S., and Campos, F. J. (1957). Cholesterol pericarditis. Ann. intern. med., 47, 817. 